\title{
LARYNGEAL CANCER:QUALITY OF LIFE AMONG PATIENTS UNDERWENT TOTAL LARYNGECTOMY
}

\author{
E. A. EL-MOSELHY, T. M. FARGHALY* and Y. M. SALEH \\ Departments of Community Medicine and Ear, Nose \& Throat* \\ Faculty of Medicine - Al-Azhar University
}

\begin{abstract}
Introduction: Laryngeal cancer is an important health problem causing negative effects on patients' quality of life (QOL). Objectives: The aim of this research is to study QOL of the patients with laryngeal cancer who underwent TL, laryngectomees, and to study impact of early speech restoration on QOL of these patients. Subjects and methods: A case-control, hospitalbased study design was used. A total number of 90 laryngectomees and a control group of the same number were enrolled in this research. Results: The laryngectomees had a significantly poorer self-reported health-related QOL domain scores than the controls on all eight Short Form (SF)-36 domains $(\mathrm{P}=0.000)$. Also, the laryngectomees with primary/secondary tracheoesophageal puncture (TEP) had significantly poorer self-reported health-related QOL domain scores than the controls on all eight SF-36 domains $(\mathrm{P}=0.000)$. Further, patients with primary TEP had significantly higher self-reported health-related QOL domain scores than the patients with secondary TEP on the social functioning, emotional limitation and mental health domain scores of SF-36 QOL with statistically significant differences $(\mathrm{P}=0.003,0.006$ and 0.019; respectively). Conclusions: Voice restoration is an important essentiality for the laryngectomees. Primary TEP is preferred over secondary TEP. Recommendations: More studies are needed on large number of patients to understand the impact of the laryngeal cancer and consequent of its therapy on QOL of these patients on short and long term.
\end{abstract}

\section{Introduction:}

Laryngeal cancer is the one of the most common malignant neoplasia of the head and neck. It accounts for $1.0-2.0 \%$ of all cancer and $11.0-22.0 \%$ of head and neck cancer (Huang, 2003). In Egypt, laryngeal cancer represents $5.7 \%$ of all body malignancies and $38.7 \%$ of the head and neck malignancies (Farghaly, 1991). Moreover, it remains the second most common respiratory cancer after lung cancer worldwide (Cattaruzza, 1996 and Mohammad et al., 2003). Also, the prevalence of laryngeal cancer is increasing over time in much countries of the world (Cattaruzza, 1996). In the past several decades, the incidence of laryngeal carcinoma has been increasing steadily in the United States (Shah et al., 1997). The incidence of laryngeal carcinoma in China was $1.79 / 100,000,2.0 / 100,000,4.3 / 100,000$ and 5.0/100,000 in 1972, 1986, 1990 and 1994, respectively ( $\mathbf{L i}$ and $\mathbf{T u}, \mathbf{2 0 0 2}$ ).
Furthermore, the number of women who are diagnosed with laryngeal cancer continues to rise (American Cancer Society, 2003).

There is a perception that total laryngectomy (TL) has a devastating effect on patients and their family members because the presence of definitive stoma and the loss of the larynx (Karnell et al., 2000). TL results in physical and functional changes that can affect the emotional wellbeing and some of the most basic functions of life, including breathing, swallowing, and communication (Doyle and Keith, 2005). Proper education and counseling from health care providers can help patients to adapt to the changes related to the procedure, but, even with strong counseling, the changes to communication and other body functions are often overwhelming for subjects and their families (Salmon, 1999). After TL, the 


\section{LARYNGEAL CANCER ....}

person breathes through a stoma in the neck that may elicit a negative reaction from the patient and from others (Dropkin, 1989). Further, re-routing of breathing through a stoma often results in increased mucus production, coughing and possibly extraneous noise during breathing. Other common issues reported after TL include dysphagia (Kazi et al., 2006), change in taste and smell (Hilgers et al., 2002), and neck and shoulder movement problems (Terrell et al., 2000). But, the alterations to voice and speech production are perhaps the most obvious. The rehabilitation process focuses heavily on re-establishing functional communication (Schuster et al., 2003). Repeated visits to the hospital, job loss, and worries of cancer recurrence can add to the psychological burden on patients and families (Stam et al., 1991). So, difficulties in one or several of these areas could negatively impact a person's perceived quality of life (QOL) (Attieh et al., 2008). In general, patients who undergone TL experience a decreased QOL compared to healthy individuals (Schuster et al., 2003).

Language that expressed through speech is a fundamental characteristic of the human being communication. Also, language loss after TL severely disrupts normal interactions with others and results in significant psychological changes. Failure to adjust language leads to, often, social withdrawal and decrease in the QOL (Clement et al., 1997). So, restoring fluent, intelligible speech to laryngectomees should have high priority (Hilgers et al., 1999). Currently, different methods for improving communication capabilities after TL are available. These modalities consist of esophageal injection speech, various electrolaryngeal devices and tracheoesophageal puncture (TEP) with insertion of valve prosthesis (Stafford, 2003 and Reynolds et al., 2006).

In the past decade, it has become increasingly common for many individuals who are laryngectomized to undergo surgical-prosthetic voice rehabilitation in the form of a TE voice restoration (Hillman et al., 1998). TE speech significantly improved the QOL and limited the voice handicap imposed by TL (Attieh et al.,
(2008). Further, it is considered the method of choice for many of the patients and physicians (success rates up to 90.0\%). Compared with other methods of communications, a higher percent of patients achieve an acceptable voice, enabling them to communicate under virtually all social circumstances (Hilgers and Balm, 1993). For some TE speakers, a voice that more closely approximates laryngeal speech may be reflected in ratings of QOL and degree of voice handicap that are more similar to non-laryngectomized speakers, although this remains to be demonstrated more definitively (Schuster et al., 2004 and Eadie \& Doyle, 2005).

QOL has become an accepted as an end point in clinical research trials in recent years, as interest in patients' experiences and preferences has grown (Patrick and Bergner, 1990). Moreover, where patient is assessed; QOL concerned (Evans et al., 2009). But, the comprehensive analysis of the literature showed that, although it is increasing, the reporting on QOL end points remains uncommon in clinical trials and the quality of the reporting is often poor (Sanders et al., 1998). In the case of laryngeal cancer, results from the use of QOL scales highlight the fact that although treatment of the cancer is sufficient (i.e., increased survival occurs), individuals continue to experience difficulties in daily activities and social participation, regardless of the type of treatment (Doyle, 1999).

QOL instruments are often used to evaluate treatment effects from the patients' point of view (Schuster et al., 2003). Such tools adopt the needs-based model of QOL, which postulates that life gains quality from the ability of individuals to satisfy their own needs (Hunt and Mckenna, 1992). Further, measuring QOL is complicated by the fact that there are many different validated questionnaires available. In addition, QOL is an individual perception that can be affected by one's health status (Vilaseca et al., 2006).

QOL used as a clinical outcome measurement is often not measured or carefully defined, but rather broadly defined to encompass an individual's perception of his/her emotional, physical, 
social, and sexual state. Simply, it is the satisfaction and well-being that a patient experiences on a daily basis (Morton and Izzard, 2003). So, QOL is defined as a measure of the optimum energy or force that endows a person with the power to cope successfully with the full range of challenges encountered in the real world. The term QOL applies to all individuals, regardless of illness or handicap, on the job, at home, or in leisure activities. Quality enrichment methods can include activities that reduce boredom and allow a maximum amount of freedom in choosing and performing various tasks (Gotay et al., 1992).

Expectation may have a greater impact on QOL than experience. The perception of the QOL varies between individuals and is dynamic within them. QOL in relation to health is the gap between our expectations of health and our experience of it. So, people with different expectations report a different QOL even when the same clinical condition is present. Current measures for QOL do not account for expectations of health (Carr et al., 2006).

Health-related QOL represents the functional effects of an illness and its consequent therapy upon a patient as perceived by the patient (Guillemin et al., 1993). However, the term QOL is, often, used vaguely and without clear definition (Fallowfield, 1996). This is not surprising, considering the broad nature of a concept that includes physical functioning (ability to carry out activities of daily living such as self care and walking around), psychological functioning (emotional and mental wellbeing), social functioning (relationships with others and participation in social activities), and perception of health status, pain, and overall satisfaction with life (Naughton and Shumaker, 1996).

The increased recognition of the patient's point of view as an important component in the assessment of health care outcomes has resulted in the development of several instruments to measure healthrelated QOL. One of the most widely used and psychometrically sound instruments is the Medical Outcomes Study 36-item Short
Form (SF-36) (Watson et al., 1996). The SF-36 is a widely accepted outcomes research tool designed to measure general health. It is a comprehensively validated instrument and continues to be the subject of an extensive program of ongoing research. It is easy to use, but researchers must be able to appreciate the nuances of their findings. This instrument allows investigators to explore the interaction and relative effect of multiple health conditions in the same patient (Hemingway et al., 1997 and Benninger et al., 1998).

The aim of the present research is to study the QOL of the patients with laryngeal cancer who underwent TL and to study impact of early speech restoration on QOL of the patients with primary/secondary TEP.

\section{Subjects and Methods:}

I- Research questions: Is there laryngeal cancer therapy, TL, impact on QOL of the laryngectomees? Is there immediate (primary) or delayed (secondary) TEP insertion to restore speech impact on QOL of the laryngectomees?

II- Research design: A case-control, hospital-based design was used to conduct this research.

III- Research setting: The patients enrolled in this research attended the Ear, Nose and Throat Outpatient Clinics, AlAzhar University Hospitals as well as some private hospitals asking for medical advice, treatment and/or follow up. Also, the control group enrolled in this research attended the same places.

IV- Research sampling: Purposive sampling design was selected. A total number of 90 patients with laryngeal cancer underwent TL and an equal number of controls were enrolled in this research.

V- Research procedure: The laryngeal cancer patients, laryngectomees, were divided to three subgroups; TL plus primary TEP group (58 patients), TL plus secondary TEP (28 patients) and TL without TEP (4 patients). The last two groups; TL plus secondary TEP and TL without TEP were grouped together (32 patients). The TL plus primary TEP group questionnaires' were filled at time of follow up, at least six months after prosthetic 
valves surgery. While, TL plus secondary TEP group questionnaires' were filled at time of prosthetic valves surgery; at least six months after TL surgery or if the voice restoration was not done tell that time. So, finally there were three groups; TL plus primary TEP (58 patients), TL without TEP (with secondary TEP/without TEP-32 patients) and the control group (90 subjects). The total group of laryngectomees was compared with controls. Then, each subgroup of the cases was compared with controls. Lastly, the two subgroups of laryngectomees were compared together.

VI- Inclusion criteria: This research was carried out on the laryngectomees plus primary TEP, secondary TEP and without TEP. The control group was chosen randomly from patients attending the clinics and proved to be free from malignancies and laryngeal diseases. The laryngeal cancer patients and controls were adults.

VII- Ethical consideration: The agreement, verbal consent, for participation of the patients and controls was taken after full explanation of the aim of the research. The participants were given the opportunity to refuse the participation, and they were notified that they could withdraw at any stage of the research. Also, they were assured that the data would be confidential and used for the research purpose only.

VIII- Tool of data collection: The Medical Outcomes Study 36-item Short Form (SF36) was used to study QOL of the patients with laryngeal cancer and underwent TL.

The SF-36 is a validated generic QOL measure containing 36 questions. This survey is currently the most widely accepted and most used measure of general health status. Each patient is scored from 0 (worst) to 100 (best) on 8 separate domains of health-related quality of life. These domains include physical functioning, role functioning-physical, bodily pain, general health, vitality, social functioning, role functioning-emotional, and mental health. It is self-administered and takes less than 10 minutes to complete, but in this research we helped the patients and control groups in filling the form. The questionnaire is scored according to published algorithms and is divided into eight subscales. These scales are ordered according to the degree to which they measure physical versus mental health. The 36-item question is distributed over the eight health domains. Questions number 3a, 3b, 3c, 3d, 3e, 3f, 3g, 3h, 3i, and $3 \mathrm{j}$ are about the physical functioning $(\mathrm{PH})$. Physical limitation (RP) questions are number 4a, 4b, 4c, and 4d. Bodily pain (BP) questions are number 7 and 8 . Questions number 1, 11a, 11b, 11c, and 11d are about general health (GH). Vitality (VT) questions are number $9 \mathrm{a}, 9 \mathrm{e}, 9 \mathrm{~g}$, and 9i. Questions number 6 and 10 are about social functioning (SF). Questions number $5 \mathrm{a}, 5 \mathrm{~b}, 5 \mathrm{c}$ are about emotional limitation (RE). Finally, mental health questions are number 9b, 9c, 9d, 9f, and 9h. The reported health transition is the question number two. The SF-36 quantifies a broad range of health issues, and is thus acceptable for an exploratory study on quality of life in conditions that may be anticipated to affect patients in a variety of ways (Ware et al., 1993).

Normative data are the key to determining whether an individual or group scores below or above the average for their country, age or sex (Fitzpatrick et al., 2001).

The reliability and validity of the SF-36 have been well documented by the developers of the instrument. A comparison of a series of generic health status measures indicated that the SF-36 is not only psychometrically sound but is also more responsive to clinical improvement than the other instruments tested. Moreover, health functioning changed in the hypothesized direction with increased age, socioeconomic status and disease status in a population-based longitudinal study of the SF-36, which suggests that the instrument is sensitive to changes in the health of the general population (Garratt, 2002).

IX- Statistical design: The collected data was organized, categorized, tabulated, and analyzed by using the computer software (Statistical Package for Social Science \{SPSS \} version 12). Suitable statistics was used for numerical data. The mean (M) was used as a measure of central tendency. The standard deviation $( \pm \mathrm{SD})$ was used as a measure of dispersion. The t-test was used 
as test of significance. The significance level for $\mathrm{t}$ was accepted if $\mathrm{P}$-value $<0.05$.

\section{Results:}

Table (1) clears means and standard deviations of the laryngeal cancer patients who underwent TL and control group according to the SF-36 QOL domain score. All the $\mathrm{M} \pm \mathrm{SD}$ of the eight domain scores of the SF-36 QOL of the laryngectomized patients were lower than that of the controls with statistically significant differences $(\mathrm{P}=0.000)$.

Table (2) shows means and standard deviations of the patients with TL plus primary TEP and the control group according to the SF-36 QOL domain score. All the $\mathrm{M} \pm \mathrm{SD}$ of the eight domain scores of the SF-36 QOL of the patients with TL and primary TEP were lower than that of the controls with statistically significant differences $(\mathrm{P}=0.000)$.

Table (3) details means and standard deviations of the patients with TL plus secondary TEP and the control group according to the SF-36 QOL domain score. All the $\mathrm{M} \pm \mathrm{SD}$ of the eight domain scores of the SF-36 QOL of the patients with TL and secondary TEP were less than that of the controls with statistically significant differences $(\mathrm{P}=0.000)$.

Table (4) illustrates means and standard deviations of the patients with TL plus primary TEP and the patients with TL plus secondary TEP according to the SF-36 QOL domain score. The $\mathrm{M} \pm \mathrm{SD}$ of the social functioning, emotional limitation and mental health domain scores of the SF-36 QOL of the patients with TL and primary TEP were higher than that of the patients with TL and secondary TEP with statistically significant differences ( $\mathrm{P}=0.003,0.006$ and 0.019; respectively).

\section{Discussion:}

The prevalence of laryngeal cancer is increasing over time in much of the world (Cattaruzza, 1996). At the same time, overall 5-year survival for all patients with laryngeal squamous cell carcinoma is approximately $67.0 \%$ (Godin et al., 2000).
Complete laryngeal tumor ablation is the first head and neck surgeons' treatment objective (Hilgers et al., 1999). At the same time, the advancement in surgical and antiseptic techniques in TL operation change surgeons' main concern from sepsis, aspiration and the lifethreatening problems gradually to focus shifted from saving a life to enhancing its quality (Shanks, 2001). Even, if successful from the standpoint of eliminating the tumor and increasing one's long-term survival, treatment for many of the head and neck cancer, including laryngeal cancer, will result in significant changes that permanently alter the individual's physical, psychological, social, emotional, nutritional, and communicative functioning, with myriad secondary influences on his/her functional status. Several specific concerns have emerged as valuable areas of clinical inquiry. Specifically, concerns of disfigurement and subsequent post treatment appearance and its social impact, changes in deglutition and swallowing, and difficulties encountered with voice and speech are all concerns that have a direct bearing on QOL (De Boer et al., 1999). Further, results from the use of QOL scales showed that while treatment of the cancer is sufficient, individuals continue to experience difficulties in daily activities and social participation (Doyle, 1999).

A diagnosis of laryngeal cancer that ultimately requires radical surgical intervention will have devastating effects on the person who experiences the disease. TL will results in significant levels of change in the physical, psychological, social, and emotional domains with an ultimate influence on the individual's judgment of his/her own QOL. Functional restrictions in these domains are further complicated by the fact that TL results in complete loss of normal verbal communication. While voice and speech may be restored through training and use of alternative methods of verbal communication listeners will always identify the quality of this new communication method as nonnormal

(Eadie and Doyle, 2005).

The treatment methods of laryngeal cancer include radiation therapy, surgery 
and chemotherapy. Methods eligible for the treatment of early stage laryngeal cancer are radiotherapy, cordectomy and partial laryngectomy. But, many of the patients have already developed to the advanced stages when they are diagnosed. For these cases, TL is indicated. After TL, a permanent stoma in the middle of the neck is left. TL would lead to many undesirable impediments for patients, such as loss of voice, alteration of the airway, excessive sputum production and cough, possible halitosis and foul smelling odor, limited mobility of the neck and shoulder, loss of nasal function and altered deglutition. After TL, not only do patients have to adapt to living with cancer, they are also possibly left with these significant problems (Lemone, 1996). If TL patients are unable to adapt to these alterations of the surgery, the physical deformities could result in psychological distress, such as depression, poor self-concept, negative attitudes of the body, and disruption of social interactions including social withdrawal and social isolation (Krouse, et al., 1989 and Mathieson et al., 1990). These effects severely influence TL patients' health and QOL (Deshmane et al., 1995), as we noticed among our patients.

TL is significantly altering the patient's QOL as voice defect is the most important for post TL patients because voice communication takes a very special role in peoples' daily life. Loss of voice after this operation has been the major concern for surgeons (Kao et al., 1994 and Jia et al., 2002). So, voice restoration after $\mathrm{TL}$ remains a challenging problem for surgeons, nurses and speech therapists. They have explored several different methods for voice rehabilitation (Zheng \& Li, 2000 and Jia et al., 2002). Further, voice restoration is, however, the key for laryngectomees to return to their normal, within limits, productive life (Hilgers et al., 1999 and Fagan et al., 2002).

$\mathrm{TE}$ voice restoration first involves creation of a midline-TE puncture and use of a one-way valved prosthesis that permits flow of pulmonary air into the esophageal reservoir. This airflow can generate a pulmonary-powered "esophageal" voice through vibration of tissues of the upper esophagus and lower pharynx. TE voice restoration has the advantage of permitting rapid restoration of voice in many patients who have undergone TL. When compared to other methods of alaryngeal voice and speech production, TE speakers are among those who exhibit frequency, intensity, and durational values that approximate those of the normal speaker (Hillman et al., 1998 and Reynolds et al., 2006). Although objective values of TE speech often fall within the normal laryngeal range, listeners clearly identify TE speakers as being perceptually less acceptable and less intelligible than normal laryngeal speakers, as well as those who have been treated with radiation but no surgical intervention (Finizia et al., 1998). These results have direct implications on social acceptance and interaction, functional communication and the adjustment of TL patients. So, the psychosocial impact of such concerns cannot be disregarded (Eadie and Doyle, 2005).

The impact of TL on QOL may change, depending on the time of analysis, and may be influenced by factors such as fear of recurrence, changes in stoma, difficulties in voice production, and side effects of chemotherapy and radiotherapy (Vilaseca et al., 2006). Also, QOL issues will differ depending on tumor site, stage, and type of treatment rendered (Wang, 2006).

QOL is dynamic, because it often changes across time and situations. In addition, health-related QOL represents the functional effects of a health problem and its therapy upon a patient as perceived by the patient him/her self (Guillemin et al., 1993). Also, QOL reflects a measure of the difference, or gap between one's perceived reality and one's expectations or wishes (Carr et al., 2006). QOL of well-being is a composite of two components; first, the ability to perform everyday activities that reflect physical, psychological and social well-being and second, patient satisfaction with levels of functioning and the control of disease and/or treatment-related symptoms (Gotay et al., 1992). Also, QOL is a subjective concept, multidimensional scope that requires information about a range of areas of patient's life such as physical 
wellbeing, functional abilities, emotional and social wellbeing (De Antonio et al., 2001). Further, QOL measures subjective experiences, patient and professional can have different perspectives on what constitutes QOL. These different perspectives make it difficult to assess QOL (Gotay et al., 1992).

The lack of clear definition of QOL is reflected in the many instruments that have been proposed to measure it. Generic measures such as the SF-36 (Ware and Sherbourne, 1992) broadly assess physical, mental, and social health and can be used to compare conditions and treatments (Guyatt et al., 1986). Further, SF-36 sensitivity to presence of otolaryngological conditions was confirmed. Otolaryngologists are likely to use health status increasingly as health care purchasers look for greater accountability in expenditure (Benninger et al., 1998).

The SF-36 questionnaire was used, in this research, to assess the QOL of the laryngectomized patients and to examine the differential impact between primary and secondary TEP on the various health status domains. Our results, confirm the sensitivity of the SF-36 to the present otolaryngological condition, agreeing with the results of many studies as Benninger et al. (1998) and El-Moselhy et al. (2008).

In this research TL was indicated for the patients in advanced stages of laryngeal cancer or after radiation therapy. $\mathrm{TL}$ is the most widely accepted surgical treatment for advanced laryngeal cancer (Silver \& Ferlito, 1996 and Fagan et al., 2002). TL considered as the last resort in the management of laryngeal cancer (Silver and Ferlito, 1996).

The SF-36, in laryngeal cancer, has been used to indicate that post-treatment health status is dependent on factors other than simple vocal handicap (Stewart et al., 1998). Loss of speech after TL severely disrupts interactions with others and results in significant psychological changes. Failure to adjust, often, leads to social withdrawal and decreases in the QOL (Fagan et al., 2002). The research reported impairment in all the eight domain scores of the SF-36. Our results were in accordance with Benninger et al., (1998); Terrell et al. (1998) and Schuster et al. (2003). The SF-36 and the Voice Handicap Inventory were used to assess QOL in a heterogeneous group of dysphonic patients, included laryngeal cancer. The dysphonic group had statistically significant reductions in a number of domains. The reductions were observed compared with US normal. These domains were social functioning, role functioning-physical, vitality, physical functioning, mental health, and role functioning-emotional (Benninger et al., 1998). Also, similar findings have been described; Schuster et al. (2003) reported differences in physical functioning and emotional role in a group of 25 laryngectomized compared with healthy German controls using the SF-36. Moreover, Terrell et al. (1998) demonstrated that individuals who undergo TL continued to report difficulty even 10 years post treatment. Also, Vilaseca et al. (2006) reported that laryngectomized had significant lower scores in physical function $(\mathrm{P}=0.005)$ and role physical $(\mathrm{P}=0.036)$.

Also, dysphonic patients without obvious laryngeal disease have an adverse impact on all health status subscales as measured by the SF-36 (Wilson et al., 2002). Further, QOL of the dysphonic patients with obvious laryngeal disease was evaluated and showed consistently worse scores of all the eight SF-36 domains. Patients revealed statistically significant reductions in QOL (Benninger et al., 1998, Spector et al., 2001 and El-Moselhy et al., 2008).

On the other hand, many reports showed that laryngectomees have a good global long-term QOL when it is measured with general health instruments and compared with norms. This suggests that the impact of TL on QOL is probably lower that one could expect and these patients have good QOL (Deleyiannis et al., 1999; Hammerlid et al., 2001 and Vilaseca et al., 2006). When QOL is assessed with questionnaires that go beyond speech and stoma, the results seem to indicate that functional impairment from TL does not diminish overall QOL as patients learn to cope with the disease (Deleyiannis et al., 1999). Further, Vilaseca et al. (2006) 
reported that laryngectomees had significant higher scores in social function $(\mathrm{P}=0.019)$ and mental health $(\mathrm{P}=0.005)$ compared with norms. While, no differences were seen in bodily pain, general health, vitality, and emotional role compared with norms. They attributed this perhaps because of using the SF-12 of SF36 , and more likely for methodological limitations. Also, the long-term and crosssectional nature of their study allowed participation of survivors only, and in addition, most of the patients were active members of support groups, and this fact may also be responsible for some of the bias.

El-Sawy (2000) compared QOL and voice analysis between TL patients with TEP and supracricoid partial laryngectomy patients. He illustrated that QOL assessments help not only to characterize the burden created by laryngeal cancer and its treatment and assist in selection between treatments but also to identify patients who are in need of rehabilitation and support to improve the quality of their survival.

The importance of alaryngeal speech on QOL after TL is controversial. However, voice restoration following TL is the key for laryngectomees to return to the productive life (Hilgers et al., 1999 and Fagan et al., 2002). Assessments of the impact of dysphonia, in laryngeal cancer, on the patient have focused on psychological and voice outcomes. Any attempts to quantify the effects of the disorder on general health and QOL have relied upon open-ended patient reports. People with dysphonia related to their laryngeal cancer experiences; social, lifestyle and employment difficulties as a direct consequence of their voice disorders (Scott et al., 1997). Further, Terrell et al. (1998) studied QOL in advanced-stage laryngeal cancer; ten years post treatment, with different instruments. The global assessment with SF-36 showed that individuals who had preserved larynges; those treated with chemotherapy (CT) and radiation therapy had significantly better mental health QOL scores on a general health survey than did those in the TL group. Individuals who had undergone TL were more depressed $(28.0 \%)$ than those individuals with intact larynges (15.0\%). However, when examining speech and communication scores, they found no differences between the two treatment groups. Also, Scott et al. (2001) used a short version of SF-36 and only reported differences on role limitations when comparing patients treated with surgery plus adjuvant radiation with a chemoradiation group. Morton (2003) in a longitudinal study found that type of treatment, site, and stage of the tumor, although influencing several factors in the somatic symptoms domain, did not impact significantly on overall QOL. While, only psychological distress was the most consistent factor in the determination of QOL over time. Also, Palmer and Graham (2004) studied the impact of communication on adjustment after TL. They cleared that the ability to communicate had the strongest association with improved QOL.

In contrast, Finizia and Bergman (2001) reported that the impact of TL on psychosocial adjustment and functional ability is comparable to that of radiation therapy, as measured with generic QOL instruments.

Patients unsuccessful in using one of the methods for improving communication capabilities after TL are left with hand and facial gesturing, mouthing words, or writing notes on paper as a mean of communication. So, this left them facing communication, psychological, social and employment problems with others in their families and communities. Furthermore, these situations might lead them to social withdrawal. TEP is one of the most developed methods in rehabilitation of the laryngectomees. In this method, one-way valve voice prosthesis is surgically inserted. The valve provides a route whereby pulmonary air can be diverted from the trachea into the esophagus, while the patient closing the stoma. This creates sound by causing a portion of the mucosa to vibrate in the pharyngeoesophageal (PE)segment (Reynolds et al., 2006). TEP speakers' measures are significantly less than the normal laryngeal voice (Pindzola and Cain, 1989). 
The QOL scores post TEP in the present study were comparable, to some what, to those from Terrell et al. (1998); Paleri et al. (2001); Eadie \& Doyle (2005) and Attieh et al. (2008). Terrell et al. (1998) and Paleri et al. (2001) both included individuals using any of the three primary alarygneal speech options.

Eadie and Doyle (2005) results' revealed, self-perceived QOL with the use of Head \& Neck (HN) QOL instrument in men with TE speech as their primary mode of post TL communication, high levels of function for all the HNQOL domains and response to treatment, as well as low levels of overall bother in.

Attieh et al. (2008) showed that the patients' scores before and after TEP voice restoration on each domain of the HNQOL were improved. This improvement for the total and domains of the HNQOL show that the patients' QOL was significantly improved in the emotions $(\mathrm{P}=0.001)$, and the total QOL score $(\mathrm{P} \leq 0.001)$. The impact that time post TL might play in the QOL ratings was calculated. The interval between TL and administration of the post TEP QOL surveys also was then correlated to the difference scores. None of these correlations was statistically significant. This suggested that the magnitude of change on QOL subsections and total scores was not closely related to how long ago they had their TL. Further, correlation coefficient between the change in Voice Handicap Inventory (VHI) total score and the change in the HNQOL total score was not statistically significant. But, there was a strong, statistically significant correlation between the VHI total score and the communication domain of the HNQOL (i.e., the impact of changes in speech after introduction of TE speech).

Lastly, the two methods of voice restoration, surgical voice restoration (SVR) as TEP and non-SVR for communication (electrolarynx, esophageal voice, writing and mouthing) outcomes were comparable. However, SVR was insignificantly $(\mathrm{P}=0.3)$ better than non-SVR (Evans et al., 2009).

Several possible reasons may account for the discrepancy among several previous reports' data, including differences in age (age is not a likely contributing factor to the higher scores observed in some reports), time post TL (no significant interaction between time post TL and QOL as measured by the HNQOL instrument in some reports), education (the high level of education and socioeconomic status reported in some reports regarding TE speakers. Education and socioeconomic status may affect an patient's knowledge of the health care system, access to services, and potential level of involvement in care. As a result, patients who are more educated may have more positive outcomes because of increased and perhaps more active involvement in treatment decisions. Educational level also may influence one's level of compliance with the recommendations of health care providers because questions may be raised and answers provided. Additionally, level of social support among better educated, and perhaps more economically stable, individuals may play a role in one's rehabilitation success), method of post TL communication (TE typically involves rapid restoration of voice after TL with resultant functional verbal communication. This certainly can positively impact psychosocial adjustment, which impacts rehabilitative success) and coping strategies (coping strategies, adjustment, social support and psychological factors also impact post TL QOL and success (De Graeff et al., 2000).

Further, the back ground cultural attitudes, in our patients, toward illness and disability may play some role in perceiving QOL. Half or more of our patients were illiterates, and had lower occupations and socioeconomic level (El-Moselhy et al., 2010). The patients felt isolated in their communities. In remote parts of the country where illiteracy are prevalent and contact with medical professionals is less likely, there is little understanding of what TL is, why the person's speech is changed, or what the available options are for communicating after surgery. Although pre-operative counseling is used to help educated patients, they often do not retain all of the information. Also, fears of cancer recurrence seem particularly high, which 
may partly be depressing the QOL ratings in the emotion domain (Attieh et al., 2008).

We reported that the mean scores of social functioning, emotional limitation and mental health domain scores of the SF36 QOL of patients with TL and primary TEP were significantly higher than that of the patients with TL and secondary TEP. This means that improvement in QOL might be related to the improvement in speech. The isolation and emotional difficulties could be related to difficulty with communication in at least some cases. Although cause can not be determined, it seems reasonable to speculate that improved communication may be at least partly responsible for the improvement in the emotion score (Attieh et al., 2008). So, an individual's social adjustment, general coping skills and overall well-being may impact the success of laryngeal speech rehabilitation. The extent to which an individual copes and adjusts to living without a larynx is presumably influenced by many variables, some of which are inherent to the individual such as their general attitude toward stress, while others might be more broadly referred to as cultural (De Maddalena, 2000; Brown et al., 2003 and Schuster et al., 2003).

On the other hand, other studies have not demonstrated a relation between QOL and speech. Stewart et al. (1998) assessed the relationship between voicerelated functional status and global health status and found that differences in voice handicap scores did not result in diminished QOL. Also, they concluded that global health status scores did not differ between patients who had undergone TL with TEP and patients treated with radiotherapy alone. Also, some individuals, although proficient TE speakers did not show much change in their QOL; they felt that the physical disfigurement following surgery was causing others to avoid them. Also, many of the patients have to come back to clinic frequently for replacement of the prosthesis due to leakage problem. So, establishment of functional TE speech apparently was not enough to counteract the negative impact on his QOL from the physical disfigurement (Attieh et al.,
2008). In addition, there has been some speculation that QOL might be differentially impacted by the method of alaryngeal communication that a person uses (Finizia and Bergman, 2001).

TEP can be performed as a primary (immediate) or a secondary (delayed) procedure. A primary puncture is performed at the same sitting of the TL operation. While, a secondary puncture is performed from 6 to 8 weeks or longer after TL or postoperative radiation therapy. In this research, secondary TEP was used as a result of surgical and/or financial problems (many of our patients can not afford money to purchase the prostheses). In this study, the time post TL that was encompassed (5.6 \pm 2.1 months from the TEP to the administration of the QOL measure) might have contributed to further adjustments to living without a larynx and, subsequently might have contributed to improvements in QOL ratings. That is, the patients might have simply had more time to integrate back into society and adapt to the changes in their life regardless of whether TE speech was introduced or not. Introduction of TE speech was the basic change in status for one group of the patients (TL plus TEP) and there were significant differences in their perceived QOL. In addition, Schuster et al. (2003) and Eadie \& Doyle (2005) did not find a significant correlation between scores on QOL instruments and the period of time since TL. Although there is evidence that with time patients learn to cope with the disease and treatment sequelae (Hammerlid et al., 2001), some studies have addressed long-term QOL after TL (Deleyiannis et al., 1999 and Palmer \& Graham, 2004). The largest changes in QOL are seen within the first year after the diagnosis, with a significant deterioration on finishing the treatment with slow recovery after that point (Hammerlid et al., 2001).

\section{Conclusions and Recommendations:}

It could be concluded that laryngeal cancer patients underwent TL had a significantly poorer self-reported healthrelated QOL domain scores than the controls on all eight SF-36 domains. Also, 
the studied laryngeal cancer cases with TL with primary and secondary TEP had significantly poorer self-reported healthrelated QOL domain scores than the controls on all eight SF-36 domains. Further, patients with primary TEP had significantly higher self-reported healthrelated QOL domain scores than the patients with secondary TEP only on the social functioning, emotional limitation and mental health domain scores of the SF-36 QOL with statistically significant differences. Lastly, we recommend that voice restoration is an important essentiality for the laryngectomees. Furthermore, primary TEP is preferred over secondary TEP. Also, more studies are needed on large number of patients to understand the impact of the laryngeal cancer and consequent of its therapy on QOL of these patients on short and long term.

\section{References:}

American Cancer Society (2003): Cancer facts and figures-2003. Atlanta (GA): American Cancer Society.

Attieh AY, Searl J, Shahaltough NH, Wreikat MM and Lundy DS (2008): Voice restoration following total laryngectomy by tracheoesophageal prosthesis: Effect on patients' quality of life and voice handicap in Jordan. Health and Quality of Life Outcomes, 6: 112-7.

Benninger MS, Ahuja AS and Gardner G (1998): Assessing outcomes for dysphonic patients. J Voice, 12: 540-50.

Brown DH, Hilgers FJM, Irish JC and Balm AJ (2003): Postlaryngectomy voice rehabilitation: state of the art at the millennium. World J Surgery, 27(7): 824-31.

Carr VI, Glaze LE, Arnold RR and Van Mersbergen $M$ (2006): Impact of voice disorders on quality of life. J Voice, 20: 17-26.

Cattaruzza MS, Maisonneuve $P$ and Boyle $P$ (1996): Epidemiology of laryngeal cancer. Eur $J$ Cancer B Oral Oncol, 32(5): 293-305.

Clement S, Rassekh H, Seikaly H, Seikaly H, Hokanson JA and Calhoun H (1997): Communication after laryngectomy: An assessment of patient satisfaction. Arch Otolaryngol Head Neck Surgery, 123:493-6.

De Antonio M, Davis J and Nilsson C (2001): Assessment of quality of life. BMJ, 317: 12904.

De Boer MF, McCormick LK, Pruyn JF, Ryckman RM, van den Borne BW (1999): Physical and psychosocial correlates of head and neck cancer: A review of the literature. Otolaryngol Head Neck Surg, 0(3): 427-36.

De Graeff A, De Leeuw JRJ, Ros WJ, Hordijk GJ, Blijham GH and Winnubst JAM (2000): Pretreatment factors predicting quality of life after treatment for head and neck cancer. Head Neck, 22(4): 398-407.

Deleyiannis FW, Weymuller EA Jr, Coltrera MD and Futran N (1999): Quality of life after laryngectomy: Are functional disabilities important? Head Neck, 21: 319-24.

De Maddalena H (2000): The influence of early speech rehabilitation with voice prostheses on the psychological state of laryngectomized patients. Eur Arch Otorhinolaryngol, 259(1): 48-52.

Doyle PC (1999): Postlaryngectomy speech rehabilitation: Contemporary considerations in clinical care. J Speech Lang Pathol Audiol, 23: 109-16.

Doyle PC and Keith RL (2005): Contemporary considerations in the treatment and rehabilitation of head and neck cancer: Voice, speech and swallowing. Austin, TX: Pro-Ed, 767.

Dropkin MJ (1989): Coping with disfigurement and dysfunction after head and neck surgery: A conceptual framework. Seminars in Oncology Nursing, 5: 213-9.

Eadie TL and Doyle PC (2005): Quality of life in male tracheoesophageal (TE) speakers. JRRD, 42:115-24.

El-Moselhy EA, Barka YA, Abd- Allah ES, Alshhorbagy TS, El-Sawy MM and Farghaly TM (2008): Risk factors and quality of life of adult patients with chronic voice disorders. Egypt J Hosp Med, 30: 90-103.

El-Moselhy EA, Saleh YM, El-Sawy MM, Abd- Allah ES, Barka YA and Farghaly TM (2010): Laryngeal cancer: Sociodemographic, life style and clinical risk factors among patients underwent total laryngectomy. Egypt $\mathrm{J}$ Hosp Med, 38: 21-37.

EL-Sawy MM (2000): Conservative surgery in larynx. Thesis for MD in Otolaryngology, Faculty of Medicine, AL-Azhar University.

Evans E, Carding P and Drinnan M (2009): The Voice Handicap Index with postlaryngectomy male voices. Internat $\mathrm{J}$ Lang Communic Disord, 44: 575-86.

Fagan J, Lentin R, Oyarzabal M, Isaacs S and Sellars $S$ (2002): Tracheoesophageal speech in a developing world community. Arch Otolaryngol Head Neck Surg, 128(1): 50-3.

Fallowfield L (1996): Quality of quality of life data. Lancet, 348: 421-2.

Farghaly TM (1991): Study of cancer larynx in our environment. MD Thesis in Otolaryngology, Faculty of Medicine, Assiut University. 
Finizia C and Bergman B (2001): Healthrelated quality of life in patients with laryngeal cancer: A post-treatment comparison of different modes of communication. Laryngoscope, 111: 918-23.

Finizia C, Hammerlid E, Westin $T$ and Lindström J (1998): Quality of life and voice in patients with laryngeal carcinoma: a posttreatment comparison of laryngectomy (salvage surgery) versus radiotherapy. Laryngoscope, 108 (10): 1566-73.

Fitzpatrick R, Davey $C$, Buxton $M$ and Jones DR (2001): Criteria for assessing patient based outcome measures for use in clinical trials. The advanced handbook of methods in evidence based health care. London: Sage: 181194.

Garratt A, Schmidt L, Mackintosh A and Fitzpatrick R (2002): Quality of life measurement: Bibliographic study of patient assessed health outcome measures. BMJ, 324(7351): 1417-23.

Godin DA, Fitzpatrick PC, Scandurro AB, et al (2000): PH-20: A novel tumor marker for laryngeal cancer. Arch Otolaryngol Head Neck Surg, 126(3): 402-4.

Gotay CC, Korn EL, McCabe MS, Moore TD and Cheson BD (1992): Building quality of life assessment into cancer treatment studies. Oncology, 6(6): 25-8.

Guillemin F, Bombardier C and Beaton D (1993): Cross-cultural adaptation of quality of life measures: Literature review and proposed guidelines. J Clin Epidemiol, 46: 1417-20.

Guyatt GH, Bombardier C and Tugwell PX (1986): Measuring disease-specific quality of life in clinical trials. Can Med Assoc J, 134: 889-95.

Hammerlid E, Silander E, Hoürnestam L and Sullivan M (2001): Health related quality of life three years after diagnosis of head and neck cancer: A longitudinal study. Head Neck, 23: $113-25$.

Hemingway H, Stafford M, Stansfield S, Shipley $M$ and Marmot M (1997): Is the SF36 a valid measure of change in population health? Results from the White hall II study. BMJ, 315: 1273-9.

Hilgers FJ, Ackerstaff A and Van As CJ (1999): Tracheoesophageal puncture: Prosthetic voice management. Curr Opinion Otolaryngo Head Neck Surg, 7 (3): 112-30.

Hilgers FJ and Balm A (1993): Long-term results of vocal rehabilitation after total laryngectomy with low-resistance, indwelling Provox voice prosthesis system. Clin Otolaryngol, 18: 517-23.

Hilgers FJ, Jansen HA, van As CJ, Polak MF, Muller MJ and Van Dam FS (2002): Long-term results of olfaction rehabilitation using the nasal airflow-inducing "polite yawning" maneuver after total laryngectomy. Arch Otolaryngol Head Neck Surg, 128: 648-54 Hillman RE, Walsh MJ, Wolf GT, Fisher SG and Hong WK (1998): Functional outcomes following treatment for advanced laryngeal cancer. Part I-voice preservation in advanced laryngeal cancer. Part II-laryngectomy rehabilitation: the state of the art in the VA system. The Department of Veterans Affairs Laryngeal Cancer Study Group. Ann Otol Rhinol Laryngol, (Suppl. 107): 2-27.

Huang HN (2003): Tumor of larynx. In: Modern otolaryngology-head and neck, (Huang HN, Ed). Shanghai, Fudan University Press, 240-1.

Jia XH, Hu H and Yu YJ (2002): Volume measurement of three different voice reconstructive methods after laryngectomy. Chinese J Otorhinolaryngol Skull Base Surg, 8(3): 202-3

Kao W, Mohr M, Kimmel A, Getch $\mathrm{C}$ and Silverman C (1994): The outcome and techniques of primary and secondary tracheoesophageal puncture. Arch Otolaryngol Head Neck Surg, 120: 301-7.

Karnell LH, Funk GF and Hoffman HT (2000): Assessing head and neck cancer patient outcome domains. Head Neck, 22: 6-11.

Kazi R, Prasad V, Venkitaraman R, Nutting CM, Clarke P, Rhys-Evans $P$ and Harrington KJ (2006): Questionnaire analysis of the swallowing related outcomes following total laryngectomy. Clin Otolaryngol, 31: 525-30.

Lemone $P$ (1996): The Upper airway disease. In: Medical-surgical nursing: Critical thinking in client care (Lemone $\mathrm{P}$ and Burke KM Eds), 1357-1359. Menlo Park: Addison-Wesley Nursing, A Division of the Benjamin. Publishing Company, Inc.

Mohammad MRA, Mohammad DA, Akbar HA et al. (2003): Opium and Risk of Laryngeal Cancer. Laryngoscope, 113(11): 1939-40.

Morton RP (2003): Studies in quality of life of head and neck cancer patients: Results of a twoyear longitudinal study and a comparative crosssectional cross-cultural survey. Laryngoscope, 113: 1091-103

Morton RP and Izzard ME (2003): Qualityof-life outcomes in head and neck cancer patients. World J Surg, 27:884-9.

Naughton MJ and Shumaker SA (1996): Assessment of health-related quality of life. In: Furberg CD, DeMets DL, eds. Fundamentals of clinical trials. 3rd ed. St Louis: Mosby Press: 322-34.

Palmer AD and Graham MS (2004): The relationship between communication and quality of life in laryngeal speakers. Speech Language Pathol Audiol, 28: 6-24. 
Patrick DL and Bergner M (1990): Measurement of health status in the 1990s. Ann Rev Public Health, 11: 165-83.

Pindzola R and Cain B (1989): Duration and frequency characteristics of tracheoesophageal speech. Ann Otol Rhinol Laryngol, 98: 960-4.

Reynolds C, Serge A, Furr A, Cunningham M, Bumpous J, Lentsch E, Banis J, Vasilic D, Storey B, Wiggins O, Maldonado C, PerezAbadia G and Barker J (2006): Risk acceptance in laryngeal transplantation. Laryngoscope, 116 (10): 1770-5.

Sanders C, Egger M, Donovan J, Tallon D and Frankel S (1998): Reporting on quality of life in randomized controlled trials: Bibliographic study. BMJ, 317: 1191-4.

Schuster M, Lohscheller J, Hoppe U, Kummer P, Eysholdt $U$ and Rosanowski F (2004): Voice handicap of laryngectomees with tracheoesophageal speech. Folia Phoniatr Logop, 56(1): 62-7.

Schuster M, Lohscheller J, Kummer P, Hoppe U, Eysholdt U and Rosanowski F (2003): Quality of life in laryngectomees after prosthetic voice restoration. Folia Phoniatr Logop, 55(2): 211-9.

Scott MM, Bumpous JM, Flynn MB and Schill K (2001): Quality of life after treatment for advanced laryngeal and hypopharyngeal cancer. Laryngoscope, 111:1379-82.

Scott S, Robinson K and Wilson JA (1997): Patient-reported problems, risk factors for squamous epithelial carcinoma of the mouth, the oropharynx, the hypopharynx and the larynx. J Otolaryngol, 28: 78-81.

Shah JP, Karnell LH, Hoffman HT, et al (1997): Patterns of cancer for cancer of the larynx in the United States. Arch Otolralayngol Head Nec Surg, 123: 475-83.

Shanks J (2001): A history of teaching speech after laryngectomy by lay instructors, 9(3): 12933.

Silver CE and Ferlito A (1996): Total laryngectomy. In: Surgery for cancer of the larynx and related structures, 2nd Ed, Silver CE and Ferlito A (eds.), WB Saunders, Philadelphia, 29-43.

Salmon SJ (1999): Some thoughts about counseling: A speech pathologist's perspective. In: Laryngeal speech rehabilitation: For clinicians by clinicians. Salmon SJ and Mount KH (Eds). Austin, TX: PRO-ED, 29-53.

Spector BC, Netterville JL, Billante C, Clary J, Reinisch L and Smith TL (2001): Qualityof-life assessment in patients with unilateral vocal cord paralysis. Otolaryngol Head and Neck Surg, 125(3): 176-82.

Stafford F (2003): Current indications and complications of tracheoesophageal puncture for voice restoration after laryngectomy. Head and neck oncology, 11(2): 89-95.

Stam H, Koopman JP and Mathieson CM (1991): The psychosocial impact of a laryngectomy: A comprehensive assessment. J Psychosocial Oncol, 9:37-58.

Stewart MG, Chen AY and Stach CB (1998): Outcomes analysis of voice and quality of life in patients with laryngeal cancer. Arch Otolaryngol Head Neck Surg, 124: 143-8.

Terrell JE, Fisher SG and Wolf GT (1998): Long-term quality of life after treatment of laryngeal cancer. Arch Otolaryngol Head Neck Surg, 124: 964-71.

Terrell JE, Welsh DE, Bradford CR, Chepeha DB, Esclamado RM, Hogikyan ND and Wolf GT (2000): Pain, quality of life, and spinal accessory nerve status after neck dissection. Laryngoscope, 110: 620-6.

Vilaseca I, Chen AY and Backscheider AG (2006): Long-term quality of life after total laryngectomy. Head Neck: 313-20.

Wang MB (2006): Quality of life following chemoradiation therapy for head and neck cancer. American Academy of OtolaryngologyHead and Neck Surgery Foundation, One Prince Street, Alexandria, VA 22314-3357.

Ware JE and Sherbourne CD (1992): The MOS 36-item short-form health survey (SF-36): Conceptual framework and item selection. Med Care, 30: 473-83.

Ware JE, Snow KK, Kosinski $M$ and Gandek B (1993): SF-36 health survey manual and interpretation guide. Boston: The Health Institute, New England Medical Center: 45-57.

Watson EK, Firman DW, Baade PD and Ring I (1996): Telephone administration of the SF-36 Health Survey: validation studies and population norms for adults in Queensland. Aust N Z J Public Health, 20: 359-63.

Wilson JA, Deary IJ, Millar A and Mackenzie K (2002): The quality of life impact of dysphonia. Clin Otolaryngol Allied Scien, 27(3): 179-82.

Zheng J and Li ZT (2000): Detectation and observation of related factors on pronunciation effect after total laryngectomy with Blom-Singer technique. Clin J Phys Med Rehabil, 22(4): 243-5. 
Table (1): Means and standard deviations of the laryngeal cancer patients with total laryngectomy (TL) and control group according to the Short Form-36 QOL domain score.

\begin{tabular}{|c|c|c|c|c|}
\hline $\begin{array}{c}\text { SF-36 } \\
\text { domain } \\
\text { score }\end{array}$ & $\begin{array}{c}\text { TL } \\
\text { patients } \\
(\mathbf{N}=90) \\
\text { Mean } \pm \\
\text { SD }\end{array}$ & $\begin{array}{c}\text { Controls } \\
(\mathbf{N}=90) \\
\text { Mean } \pm \\
\text { SD }\end{array}$ & $\mathbf{t}$ & $\begin{array}{c}\text { P- } \\
\text { value }\end{array}$ \\
\hline $\begin{array}{r}\text { Physical } \\
\text { functioning }\end{array}$ & $\begin{array}{c}53.42 \pm \\
10.24\end{array}$ & $\begin{array}{c}84.96 \pm \\
12.52\end{array}$ & $\begin{array}{c}- \\
18.499 \\
\end{array}$ & 0.000 \\
\hline $\begin{array}{r}\text { Physical } \\
\text { limitation }\end{array}$ & $\begin{array}{c}49.13 \pm \\
8.77\end{array}$ & $\begin{array}{c}85.79 \pm \\
12.62 \\
\end{array}$ & $\begin{array}{c}- \\
22.631 \\
\end{array}$ & 0.000 \\
\hline $\begin{array}{r}\text { Bodily } \\
\text { pain }\end{array}$ & $\begin{array}{c}55.70 \pm \\
13.19\end{array}$ & $\begin{array}{c}78.84 \pm \\
14.17\end{array}$ & -11.34 & 0.000 \\
\hline $\begin{array}{r}\text { General } \\
\text { health }\end{array}$ & $\begin{array}{c}53.53 \pm \\
10.12\end{array}$ & $\begin{array}{c}75.79 \pm \\
15.88\end{array}$ & $\begin{array}{c}- \\
11.215\end{array}$ & 0.000 \\
\hline Vitality & $\begin{array}{c}48.35 \pm \\
8.07\end{array}$ & $\begin{array}{c}73.71 \pm \\
16.06 \\
\end{array}$ & $\begin{array}{c}- \\
13.386 \\
\end{array}$ & 0.000 \\
\hline $\begin{array}{r}\text { Social } \\
\text { functioning }\end{array}$ & $\begin{array}{c}54.03 \pm \\
9.90\end{array}$ & $\begin{array}{c}86.51 \pm \\
12.44\end{array}$ & $\begin{array}{c}- \\
19.381\end{array}$ & 0.000 \\
\hline $\begin{array}{c}\text { Emotional } \\
\text { limitation }\end{array}$ & $\begin{array}{c}57.95 \pm \\
12.64 \\
\end{array}$ & $\begin{array}{c}84.70 \pm \\
13.18 \\
\end{array}$ & $\begin{array}{c}- \\
13.897\end{array}$ & 0.000 \\
\hline $\begin{array}{r}\text { Mental } \\
\text { health }\end{array}$ & $\begin{array}{c}60.74 \pm \\
13.72\end{array}$ & $\begin{array}{c}77.34 \pm \\
16.74\end{array}$ & -7.276 & 0.000 \\
\hline
\end{tabular}

Table (2): Means and standard deviations of the patients with total laryngectomy (TL) and primary tracheoesophageal puncture (TEP) and the control group according to the Short Form-36 QOL domain score.

\begin{tabular}{|c|c|c|c|c|}
\hline $\begin{array}{c}\text { SF-36 } \\
\text { domain } \\
\text { score }\end{array}$ & $\begin{array}{c}\text { TL plus } \\
\text { primary } \\
\text { TEP } \\
(\mathrm{N}=58) \\
\text { Mean } \pm \\
\text { SD }\end{array}$ & $\begin{array}{c}\text { Control } \\
\text { Group } \\
(\mathbf{N}=90) \\
\text { Mean } \pm \\
\text { SD }\end{array}$ & $\mathbf{t}$ & $\begin{array}{c}\text { P- } \\
\text { value }\end{array}$ \\
\hline $\begin{array}{r}\text { Physical } \\
\text { functioning }\end{array}$ & $\begin{array}{c}56.21 \pm \\
10.68 \\
\end{array}$ & $\begin{array}{c}84.96 \pm \\
12.52 \\
\end{array}$ & -14.93 & 0.000 \\
\hline $\begin{array}{r}\text { Physical } \\
\text { limitation }\end{array}$ & $\begin{array}{c}50.65 \pm \\
8.84 \\
\end{array}$ & $\begin{array}{c}85.79 \pm \\
12.62 \\
\end{array}$ & $\begin{array}{c}- \\
19.904 \\
\end{array}$ & 0.000 \\
\hline $\begin{array}{r}\text { Bodily } \\
\text { pain }\end{array}$ & $\begin{array}{c}56.86 \pm \\
13.67\end{array}$ & $\begin{array}{c}78.84 \pm \\
14.17\end{array}$ & -9.413 & 0.000 \\
\hline $\begin{array}{r}\text { General } \\
\text { health }\end{array}$ & $\begin{array}{c}56.82 \pm \\
10.47\end{array}$ & $\begin{array}{c}75.79 \pm \\
15.88\end{array}$ & -8.758 & 0.000 \\
\hline Vitality & $\begin{array}{c}49.84 \pm \\
8.68\end{array}$ & $\begin{array}{c}73.71 \pm \\
16.06\end{array}$ & $\begin{array}{c}- \\
11.696 \\
\end{array}$ & 0.000 \\
\hline $\begin{array}{r}\text { Social } \\
\text { functioning }\end{array}$ & $\begin{array}{c}57.61 \pm \\
10.01\end{array}$ & $\begin{array}{c}86.51 \pm \\
12.44\end{array}$ & $\begin{array}{c}- \\
15.566\end{array}$ & 0.000 \\
\hline $\begin{array}{c}\text { Emotional } \\
\text { limitation }\end{array}$ & $\begin{array}{c}59.87 \pm \\
13.14\end{array}$ & $\begin{array}{c}84.70 \pm \\
13.18\end{array}$ & $\begin{array}{c}- \\
11.209\end{array}$ & 0.000 \\
\hline $\begin{array}{r}\text { Mental } \\
\text { health }\end{array}$ & $\begin{array}{c}62.61 \pm \\
14.22 \\
\end{array}$ & $\begin{array}{c}77.34 \pm \\
16.74 \\
\end{array}$ & -5.734 & 0.000 \\
\hline
\end{tabular}


Table (3): Means and standard deviations of the patients with total laryngectomy (TL) and secondary tracheoesophageal puncture (TEP) and the control group according to the Short Form-36 QOL domain score.

\begin{tabular}{|c|c|c|c|c|}
\hline $\begin{array}{c}\text { SF-36 } \\
\text { domain } \\
\text { score }\end{array}$ & $\begin{array}{c}\text { TL plus } \\
\text { secondary } \\
\text { TEP }(\mathrm{N}= \\
\text { 32) } \\
\text { Mean } \pm \\
\text { SD }\end{array}$ & 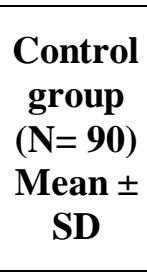 & $\mathbf{t}$ & $\begin{array}{c}P- \\
\text { value }\end{array}$ \\
\hline $\begin{array}{c}\text { Physical } \\
\text { functioning }\end{array}$ & $\begin{array}{c}52.13 \pm \\
10.09\end{array}$ & $\begin{array}{c}84.96 \pm \\
12.52\end{array}$ & 14.796 & 0.000 \\
\hline $\begin{array}{l}\text { Physical } \\
\text { limitation }\end{array}$ & $\begin{array}{c}48.09 \pm \\
8.37\end{array}$ & $\begin{array}{c}85.79 \pm \\
12.62\end{array}$ & 18.948 & 0.000 \\
\hline $\begin{array}{l}\text { Bodily } \\
\text { pain }\end{array}$ & $\begin{array}{c}54.17 \pm \\
13.10\end{array}$ & $\begin{array}{c}78.84 \pm \\
14.17\end{array}$ & -8.952 & 0.000 \\
\hline $\begin{array}{c}\text { General } \\
\text { health }\end{array}$ & $\begin{array}{c}53.03 \pm \\
10.02\end{array}$ & $\begin{array}{c}75.79 \pm \\
15.88\end{array}$ & -9.339 & 0.000 \\
\hline Vitality & $\begin{array}{c}47.12 \pm \\
8.01\end{array}$ & $\begin{array}{c}73.71 \pm \\
16.06 \\
\end{array}$ & 12.048 & 0.000 \\
\hline $\begin{array}{c}\text { Social } \\
\text { functioning }\end{array}$ & $\begin{array}{c}51.21 \pm \\
9.20\end{array}$ & $\begin{array}{c}86.51 \pm \\
12.44\end{array}$ & $\begin{array}{c}- \\
16.897\end{array}$ & 0.000 \\
\hline $\begin{array}{l}\text { Emotional } \\
\text { limitation }\end{array}$ & $\begin{array}{l}52.41 \pm \\
11.14\end{array}$ & $\begin{array}{c}84.70 \pm \\
13.18\end{array}$ & 13.398 & 0.000 \\
\hline $\begin{array}{l}\text { Mental } \\
\text { health }\end{array}$ & $\begin{array}{c}58.10 \pm \\
12.28\end{array}$ & $\begin{array}{c}77.34 \pm \\
16.74\end{array}$ & -6.878 & 0.000 \\
\hline
\end{tabular}


Table (4): Means and standard deviations of the patients with total laryngectomy (TL) and primary tracheoesophageal puncture (TEP) and the patients with TL and secondary TEP according to the Short Form-36 QOL domain score.

\begin{tabular}{|c|c|c|c|c|}
\hline $\begin{array}{c}\text { SF-36 } \\
\text { domain } \\
\text { score }\end{array}$ & $\begin{array}{c}\text { TL } \\
\text { group } \\
\text { plus } \\
\text { primary } \\
\text { TEP } \\
(\mathbf{N}=58) \\
\text { Mean } \pm \\
\text { SD } \\
\end{array}$ & $\begin{array}{c}\text { TL group } \\
\text { plus } \\
\text { secondary } \\
\text { TEP(N= } \\
\text { 32) } \\
\text { Mean } \pm \\
\text { SD }\end{array}$ & $\mathbf{t}$ & $\begin{array}{c}P- \\
\text { value }\end{array}$ \\
\hline $\begin{array}{c}\text { Physical } \\
\text { functioning }\end{array}$ & $\begin{array}{c}56.21 \pm \\
10.68\end{array}$ & $\begin{array}{c}52.13 \pm \\
10.09\end{array}$ & 1.798 & 0.075 \\
\hline $\begin{array}{c}\text { Physical } \\
\text { limitation }\end{array}$ & $\begin{array}{l}50.65 \pm \\
8.84\end{array}$ & $\begin{array}{c}48.09 \pm \\
8.37\end{array}$ & 1.361 & 0.178 \\
\hline $\begin{array}{c}\text { Bodily } \\
\text { pain }\end{array}$ & $\begin{array}{c}56.86 \pm \\
13.67\end{array}$ & $\begin{array}{c}54.17 \pm \\
13.10\end{array}$ & 0.918 & 0.363 \\
\hline $\begin{array}{c}\text { General } \\
\text { health }\end{array}$ & $\begin{array}{c}56.82 \pm \\
10.47\end{array}$ & $\begin{array}{l}53.03 \pm \\
10.02\end{array}$ & 1.69 & 0.097 \\
\hline Vitality & $\begin{array}{c}49.84 \pm \\
8.68 \\
\end{array}$ & $\begin{array}{c}47.12 \pm \\
8.01 \\
\end{array}$ & 1.496 & 0.141 \\
\hline $\begin{array}{c}\text { Social } \\
\text { functioning }\end{array}$ & $\begin{array}{c}57.61 \pm \\
10.01\end{array}$ & $\begin{array}{l}51.21 \pm \\
9.20\end{array}$ & 3.061 & 0.003 \\
\hline $\begin{array}{l}\text { Emotional } \\
\text { limitation }\end{array}$ & $\begin{array}{c}59.87 \pm \\
13.14\end{array}$ & $\begin{array}{l}52.41 \pm \\
11.14\end{array}$ & 2.849 & 0.006 \\
\hline $\begin{array}{l}\text { Mental } \\
\text { health }\end{array}$ & $\begin{array}{l}62.61 \pm \\
14.22\end{array}$ & $\begin{array}{c}56.10 \pm \\
11.10\end{array}$ & 2.403 & 0.019 \\
\hline
\end{tabular}




\section{سرطان الحنجرة: جودة الحياة}

لاى المرضى المعالجين بالإستئصسال الكلى للحنجرة

\section{عصام عبل المنعم المصيلحى - طلعت محروس فرغلى* يحيى محمد صالح قسم طب المجتمع ـ الأنف والأنن والحنجرة معرة \\ كلية الطب - جامعة الأزهر}

يُمثل سرطان الحنجرة مشكلة صحية مهمة ذات تأثير ات سلبية على مختلف مجالات جودة حباة المرضـى المعـالجين بالإستئصسال الكلى للحنجـرة. وكـان الهـف من هذا البحث هو دراسـة جـودة حيـاة

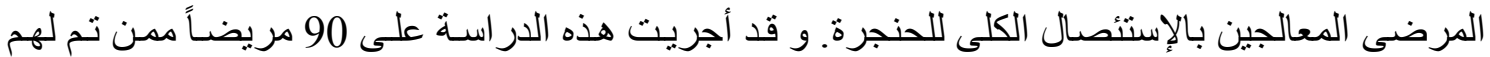
عمل استنئصـال كلى للحنجرة من مرضـى سـرطان الحنجرة وكذلك عدد مسـاوٍ مـن الأشـخاص السـالمين

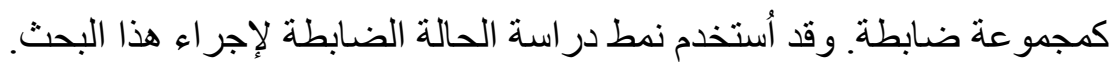

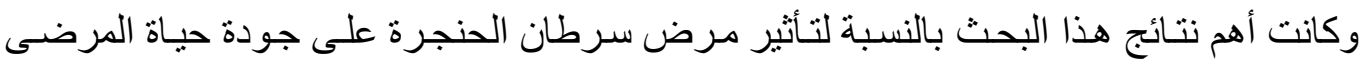
المعالجين بالإستئصسال الكلى للحنجرة أنهم قد سـلو ا مستويات أقل ممـا سجل أقر اد المجموعـة الضـابطة وذللك فى كل المجالات الثمانية لاستبيان جودة الحياة وذلك بفروق ذات دلالة إحصـائية مؤثرة. وكذللك فإن

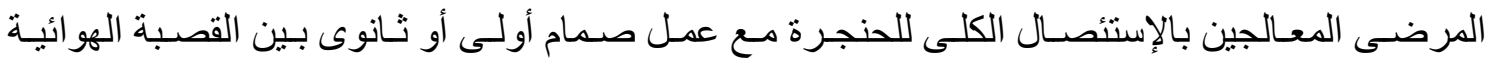

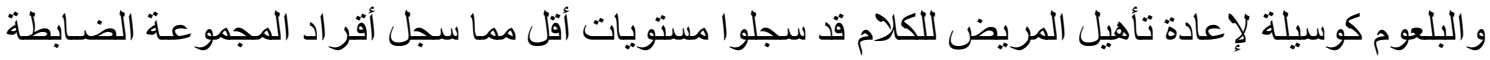
و ذلك فى كل المجالات الثمانية لاستبيان جودة الحياة وذلك بفروق ذات دلالة إحصـائية مؤثرة. وبالنسبة للمرضى المعالجين بالإستئصال الكلى للحنجرة مع عمل صمام أولى (أثناء الإستئصال الكلى للحنجرة) بين القصبة الهو ائية و البلعوم كوسيلة لإعادة تأهيل المريض للكلام قد سجلو المستويات أعلى مما سجل المرضى الإنى

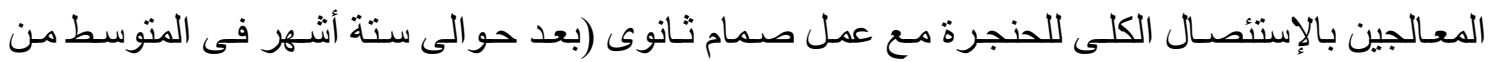

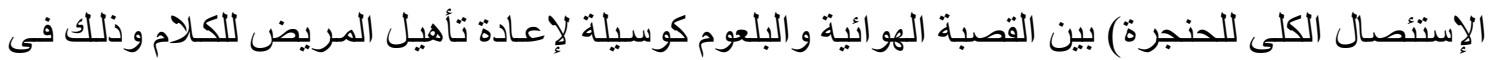
مجالات الوظيفة الإجتماعية و القصور الإنفعالى و الصحة الذهنية من مجالات استبيان جودة الحياة وذلك بفروق ذات دلالة إحصائية مؤثرة.

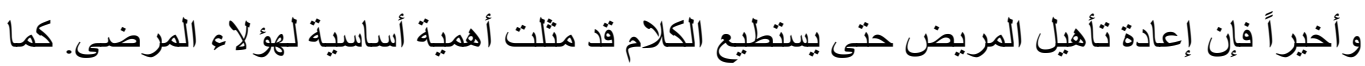

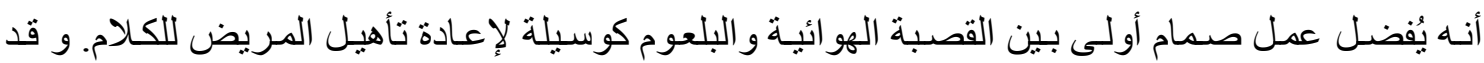

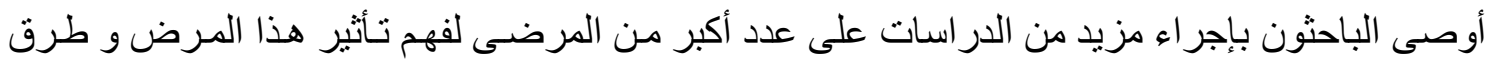

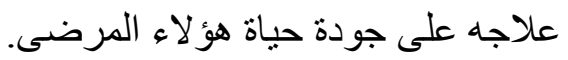

